\title{
Pemberian Asuhan Keperawatan secara Holistik pada Pasien Post Operasi Kanker Payudara
}

\author{
Mawar Eka Putri ${ }^{1}$, Urip Rahayu ${ }^{2}$ \\ ${ }^{1}$ Stikes Hang Tuah Tanjungpinang Kepulauan Riau, ${ }^{2}$ Fakultas Keperawatan, Universitas Padjadjaran \\ Email: mawarekaagustiar@gmail.com
}

\begin{abstract}
Abstrak
Kanker payudara merupakan salah satu penyakit yang ditakuti menyerang pada perempuan dan dapat mengakibatkan kematian yang paling besar bagi perempuan di usia 18 sampai 54 tahun, pada perempuan yang berusia 45 tahun memiliki resiko terjangkit kanker payudara $25 \%$ lebih tinggi dibandingkan perempuan yang lebih tua. Kanker payudara dapat menyebabkan pengaruh pada beberapa dimensi yang mengalami oleh pasien yaitu dimensi fisik seperti gangguan tidur, nyeri, merasa tidak berdaya, kelelahan dan mobilitas yang terganggu. Pengobatan kanker payudara memerlukan beberapa terapi dalam pelaksanaannya, seperti lumpektomi, mastektomi, radiasi, terapi hormon, dan kemoterapi. Pasien kanker payudara memerlukan asuhan keperawatan yang holistik (menyeluruh), sehingga kebutuhan pasien dapat terpenuhi. Tujuan pemberian asuhan keperawatan ini agar memahami etiologi, manisfestasi klinik, faktor risiko pasien kanker payudara, lebih memahami asuhan keperawatan pasien kanker payudara, dan mengidentifikasi evidence based terkait kondisi pasien kanker payudara. Metode pelaksanaan pemberian asuhan keperawatan dilakukan melalui beberapa proses pemberian asuhan keperawatan yaitu pengkajian, analisis data, diagnosis keperawatan, intervensi dan evaluasi pasien kanker payudara di Rumah Sakit Garut. Didapatkan 3 masalah keperawatan yang muncul yaitu nyeri akut, hambatan mobilitas fisik, dan kurangnya pengetahuan pasien terkait masalah kesehatan yang dialami pada pasien saat ini. Setelah dilakukan pemberian asuhan keperawatan permasalahan pasien teratasi. Tindakan asuhan keperawatan berdasarkan evidence based yaitu dengan pemberian terapi yoga dan aromaterapi mawar sebagai intervensi nyeri, dan kelelahan pada kanker juga aman, efektif dan bermanfaat dalam mengurangi intensitas nyeri, kelelahan, berkurang rasa sakitnya, mual dan kecemasan dan melaporkan peningkatan kualitas hidup.
\end{abstract}

Kata kunci: Asuhan keperawatan, holistik, kanker payudara, post operasi

\begin{abstract}
Breast cancer is a disease that is feared to attack women and can cause the greatest death for women aged 18 to 54 years, for women aged 45 years have a risk of contracting breast cancer $25 \%$ higher than older women. Breast cancer can cause effects on several dimensions experienced by the patient namely physical dimensions such as sleep disturbance, pain, feeling helpless, fatigue and impaired mobility. Treatment of breast cancer requires several therapies in its implementation, such as lumpectomy, mastectomy, radiation, hormone therapy, and chemotherapy. Breast cancer patients need holistic nursing care, so that the patient's needs can be met. Objective providing this nursing care in order to understand etiology, clinical manifestation, risk factors for breast cancer patients, better understand breast cancer patient nursing care, and identify evidence based on the condition of breast cancer patients. Methods implementation of nursing care provision by carrying out the first stage of the process of giving nursing care that is assessment, data analysis, nursing diagnoses, intervention and evaluation of breast cancer patients at Garut Hospital. There were 3 nursing problems that emerged namely acute pain, physical mobility barriers, and lack of patient knowledge related to health problems experienced in patients at this time. After giving nursing care the patient's problem is resolved. Nursing care measures based on evidence based, namely the provision of yoga therapy and rose aromatherapy as pain interventions, and fatigue in cancer are also safe, effective and beneficial in reducing the intensity of pain, fatigue, reduced pain, nausea and anxiety and report improvements in quality of life.
\end{abstract}

Keywords: Breast cancer, holistic, nursing care, post-surgery. 


\section{Pendahuluan}

Kanker payudara merupakan salah satu penyakit yang ditakuti menyerang pada perempuan dan dapat mengakibatkan kematian. Kanker payudara merupakan penyebab kematian yang paling besar bagi perempuan di usia 18 sampai 54 tahun, dan pada perempuan yang berusia 45 tahun memiliki resiko terjangkit kanker payudara $25 \%$ lebih tinggi dibandingkan perempuan yang lebih tua (Lee, 2008). Data Riset Kesehatan Dasar per 31 Januari 2019 kanker payudara yang berkembang di Indonesia mencapai 42,1 per 100.000 perempuan dimana rata-rata kematian mencapai 17 per 100.000 penduduk. Prevalensi dan estimasi di Jawa Barat penderita kanker payudara ebesar 0,3\% dengan estimasi jumlah 6.701 perempuan (Kementrian Kesehatan Republik Indonesia, 2009).

Kanker payudara dapat menyebabkan pengaruh pada beberapa dimensi pada pasien yang mengalaminya yaitu dimensi fisik seperti gangguan tidur, nyeri, merasa tidak berdaya, kelelahan dan mobilitas yang terganggu. Pada dimensi sosial, pasien yang mengalami kanker payudara mengalami beban finansial seperti biaya pengobatan yang cukup besar dan pasien yang merasa terisolir. Pada dimensi psikologi pasien mengalami perasaan penuh ketidak pastian, depresi dan kecemasan. Lebih lanjut pada dimensi spiritual terjadi perasaan bersalah, terjadi konflik batin untuk menerima kondisi, dan menolak kenyataan sakit (Lubis \& Hasnida, 2009; Tigaria, Iranmanesh, Farel, \& Kalantari, 2012).

Penatalaksanaan yang diberikan pada pasien kanker payudara dilakukan dengan serangkaian pengobatan. Pengobatan kanker payudara memerlukan beberapa terapi dalam pelaksanaannya, seperti lumpektomi, masektomi, radiasi, terapi hormon, dan kemoterapi. Lebih lanjut terapi yang diberikan tersebut tidak hanya dapat menghambat pertumbuhan sel kanker, namun berdampak pula pada fisik dan psikologis pasien. Pasien akan kehilangan payudara, kulit akan menghitam, rambut rontok, dan tubuh menjadi kurus. Lebih lanjut gejala lain yang muncul akibat kanker payudara dan perawatannya adalah gangguan tidur, nyeri, kelelahan, hilangnya fungsi fisik, sarcopenia, cachexia, pengeroposan tulang dan gangguan kognitif (Mustian, Cole, Lin \& Asare, 2016). Pada kondisi seperti itu, pasien memerlukan asuhan keperawatan yang holistik untuk memenuhi kebutuhan dasar yaitu kebutuhan biologis, psikologis, sosial, kultural, dan spiritual. Dimana kebutuhan biologis meliputi nutrisi, cairan, dan pakaian. Kebutuhan psikologis meliputi perhatian dan dukungan dari keluarga serta orang disekitar. Kebutuhan sosial meliputi interaksi dengan kelurga, teman dan masyarakat. Kebutuhan kultural yang meliputi kebiasaan dan budaya yang dianut oleh pasien. Dan kebutuhan spiritual meliputi kebutuhan pasien terhadap kepercayaan yang dianut serta hubungannya dengan Tuhan (Fan dan Chow, 2007; Costa et al, 2013; Oteami, 2014). 
Pasien kanker payudara memiliki beberapa masalah keperawatan yang kompleks dan sangat memerlukan asuhan keperawatan yang holistik (menyeluruh), sehingga kebutuhan pasien dapat terpenuhi. Berdasarkan uraian tersebut diatas penulis tertarik untuk memberikan asuhan keperawatan dengan judul "Pemberian Asuhan Keperawatan Secara Holistik Pada Pasien Kanker Payudara".

Tujuan dari pemberian asuhan keperawtan ini adalah agar memahami etiologi, manisfestasi klinik, faktor risiko pasien kanker payudara, lebih memahami asuhan keperawatan pada pasien kanker payudara, dan mengidentifikasi evidence based terkait kondisi pasien kanker payudara.

\section{Metode}

Metode pelaksanaan pemberian asuhan keperawatan ini adalah dengan dilakukannya tahapan proses pemeberian asuhan keperawatan yaitu:

1. Pengkajian

2. Analisis data

3. Diagnosis keperawatan

4. Intervensi dan evaluasi pada pasien kanker payudara di Rumah Sakit Garut.

Pada tahap pengkajian dalam upaya mengumpulkan data dan informasi yang benar, kemudian menegakkan diagnosis keperawatan berdasarkan pada analisis data dan membuat langkah atau cara pemecahan masalah, melaksanakan tindakan keperawatan sesuai dengan rencana yang ada dan memerlukan evaluasi berdasarkan respon klien terhadap tindakan keperawatan yang telah dilakukan.

Pada kasus ini pasien mengalami kanker payudara sejak \pm 2 tahun yang lalu. Klien mengatakan awalnya klien tidak mengatahui jika mengalami penyakit ini. Klien hanya merasakan ada benjolan di payudara sebelah kanan. Klien merasakan benjolan tersebut semakin hari semakin membesar. Kemudian klien dilakukan oprasi kanker payudara pada bulan Agustus, namun klien tidak melakukan perawatan dengan baik sempai terjadi penumpukan masa dinodul pada payudara sebelah kanan. Pada tanggal 13 November 2018 klien dilakukan tindakan operasi biopsi. Saat dilakukan pengkajian didapatkan data klien mengalami nyeri lemas tidak berdaya karena baru selesai dilakukan tindakan operasi, klien tampak pucat dan lemas, klien mengatakan tidak memahami akan penyakitnya sehingga dibutuhkan beberapa intervensi keperawatan maupun kolaborasi. Pada kasus ini penyebab yang muncul terjadinya kanker paydura dikarenakan gaya hidup dimana pasien tidak pernah 
menjaga pola makan. Namun untuk faktor riwayat keluarga tidak ditemukan karena kasus ini baru muncul pada pasien.

Dilakukan kajian kepada pasien dimana bertujuan untuk mendapatkan data kondisi pasien di rumah sakit dari sisi asuhan keperawatan. Dengan dilakukannya wawancara kepada pasien kelolaan maka didapatkan hasil analisis data pada kasus ini adalah:

\begin{tabular}{|c|c|c|c|}
\hline No & $\begin{array}{r}\text { Data Klien } \\
\end{array}$ & Etiologi & Masalah \\
\hline 1. & $\begin{array}{l}\text { Data subjektif: } \\
\text { - Klien mengeluh nyeri } \\
\text { Data objektif: } \\
\text { - Klien tampak meringis } \\
\text { - } \quad \text { Pasien tampak lemas } \\
\text { Skala nyeri } 5 \\
\text { - Tanda-tanda Vital : } \\
\text { TD: } 110 / 80, \text { suhu: nadi } 84 \mathrm{x} / \mathrm{mnt}, \mathrm{RR} \\
23 \mathrm{x} / \mathrm{mnt}, \\
\text { suhu } 36,1^{\circ} \mathrm{C}\end{array}$ & $\begin{array}{c}\text { Pasca operasi kanker } \\
\text { payudara } \\
\downarrow \\
\text { Terputusnya } \\
\downarrow \\
\text { inkontinuitas jaringan } \\
\text { Merangsang } \\
\text { pengeluaran zat } \\
\text { mediator nyeri } \\
\downarrow \\
\text { Nyeri Akut }\end{array}$ & Nyeri Akut \\
\hline 2. & $\begin{array}{l}\text { DS: } \\
\text { - Klien mengeluh lemas dan lelah } \\
\text { DO: } \\
\text { - Klien tampak tidur di tempat tidur } \\
\text { - Kekuatan otot } \\
\begin{array}{r|l}5 & 4 \\
& \text { ROM tangan kanan terbatas }\end{array}\end{array}$ & $\begin{array}{c}\text { Ca. Mamae } \\
\downarrow \\
\text { Meningkatnya } \\
\text { Kortisol } \\
\downarrow \\
\text { Menimbulkan Gang. } \\
\text { Metabolisme, } \\
\text { Gangguan Tidur, } \\
\text { Hipertensi, Penurunan } \\
\text { Kekebalan Tubuh } \\
\downarrow \\
\text { Fatigue } \\
\downarrow \\
\text { Hambatan Mobilitas } \\
\text { Fisik }\end{array}$ & $\begin{array}{c}\text { Hambatan } \\
\text { mobilitas fisisk }\end{array}$ \\
\hline 3. & 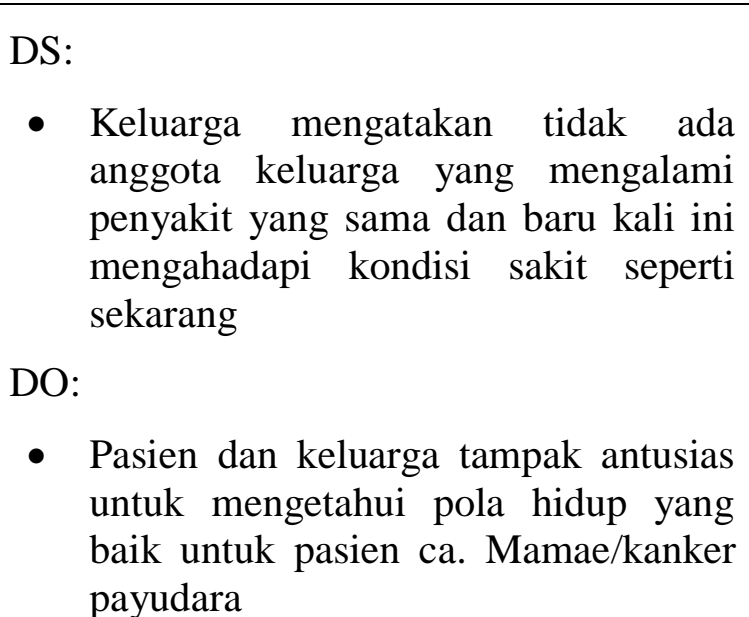 & $\begin{array}{c}\text { Kurangnya } \\
\text { pemahaman pasien } \\
\text { dan kluarga tentang } \\
\text { penangananan kondisi } \\
\text { kesehatan saat ini } \\
\downarrow \\
\text { Defisiensi } \\
\text { pengetahuan }\end{array}$ & $\begin{array}{c}\text { Kurangnya } \\
\text { pemahaman } \\
\text { pasien terkait } \\
\text { masalah } \\
\text { kesehatan yang } \\
\text { dialami saat ini }\end{array}$ \\
\hline
\end{tabular}


Dengan masalah klien tersebut maka dapat diangkat diagnosa nyeri akut, hambatan mobilitas fisik dan kurang pengetahuan. Intervensi yang dapat dilakukan adalah penanganan manajemen nyeri, penangana kelelahan, dan pendidikan kesehatan. Waktu pengkajian dilaksanakan pada tanggal 16 November - 18 November 2018 di Rumah Sakit Garut.

\section{Hasil}

Dari hasil analisis data tersebut maka dilakukan tindakan selanjutnya yaitu pemberian intervensi keperawatan kepada pasien dan kemudian dilakukan evaluasi dari tindakan keperawatan tersebut. Hasil proses analisis tersebut didapatkan 3 masalah keperawatan yang muncul yaitu nyeri akut, hambatan mobilitas fisik, dan kurangnya pengerahuan pasien terkait masalah kesehatan yang dialami pada pasien saat ini.

Pada pasien kanker payudara pasca operasi akan mengalami nyeri akut. Nyeri akut adalah suatu pengalaman sensori dan emosional tidak menyenangkan yang mengakibatkan kerusakan jaringan actual ataupun potensial yang digambarkan sebagai kerusakan International Association for the Study of Pain. Tujuan dan kriteria evaluasi pada nyeri akut adalah a) Tingkat kenyamanan: tingkat persepsi positif terhadap kemudahan fisik psikologis; b) Pengendalian nyeri: tindakan individu untuk mengendalikan nyeri; c) Tingkat nyeri: keparahan nyeri yang dapat diamati atau dilaporkan. Rangkaian selanjutnya dalam pemberian asuhan keperawatan adalah memberikan intervensi.

Beberapa intervensi yang dapat diberikan pada pasien dengan masalah nyeri akut yang terdiri dari: 1) Pengkajian: a) Gunakan laporan dari pasien sendiri sebagai pilihan pertama untuk mengumpulkan informasi pengkajian yaitu: b) Minta pasien untuk menilai nyeri dengan skala 0-10; c) Gunakan bagan alir nyeri untuk memantau peredaan nyeri oleh analgesik dan kemungkinan efek sampingnya; d) Kaji dampak agama, budaya dan kepercayaan, dan lingkungan terhadap nyeri dan respon pasien; e) Dalam mengkaji nyeri pasien, gunakan kata-kata yang sesuai usia dan tingkat perkembangan pasien, kaji nyeri pasien saat melakukan perawatan luka operasi. 2) Manajemen nyeri: a) Lakukan tindakan pengkajian nyeri secara menyeluruh yang terdiri dari, karakteristik nyeri, lokasi nyeri, durasi nyeri, frekuensi nyeri, kualitas, intensitas dari keparahan nyeri dan faktor presipitasinya; b). Observasi isyarat nonverbal ketidaknyamanan, khususnya pada mereka yang tidak mampu berkomunikasi efektif; c). Berikan informasi mengenai nyeri, seperti penyebab nyeri, berapa lama nyeri akan dirasana dan antisipasi dari ketidak nyamanan akibat prosedur; d). Ajarkan penggunaan teknik non farmakologis. 3) Pendidikan kesehatan manajemen nyeri: a). Berikan informasi yang akurat untuk meningkatkan pengetahuan dan respon keluarga terhadap 
respon nyeri; b). Libatkan keluarga dalam modalitas penurunan nyeri jika memungkinkan; c). Informasikan tim kesehatan lain atau anggota keluarga mengenai strategi nonfarmakologi yang sedang digunakan untuk mendorong pendekatan preventif terkait manajemen nyeri. Setelah dalakukan pengkajian selama 3x24 jam masalah keperawatan nyeri kronis teratasi dengan kriteria hasil skala nyeri menurun.

Masalah keperawatan yang muncul pada pasien kanker payudara post operasi akan mengalami hambatan mobilitas fisik. Definisi dari hambatan mobilitas fisik adalah keterbatasan dalam gerakan fisik, satu atau lebih ekstremitas secara mandiri dan terarah. Batasan karakteristik pada hambatan mobilitas fisik adalah a) Penurunan waktu reaksi; b) Kesulitan membolak-balikan posisi; c) Melakukan aktifitas lain sebagai pengganti pergerakan; d) Dipsnea setelah beraktifitas; e) Perubahan cara berjalan; f) Gerakan bergetar; g) Keterbatasan kemampuan melakukan keterampilan motorik halus; h) Keterbatasan kemampuan melakukan keterampilan motorik kasar; i). Keterbatasan rentang gerak sendi; j) Tremor akibat pergerakan; k) Ketidak seimbangan postur; 1). Pergerakan tidak terkoordinir.

Adapun tujuan dan kriteria hasil dari hambatan mobilitas fisik adalah: a) Joint Movement: Active; b) Mobility level; c) Self care: ADLs; d) Transfer performance. Dengan adanya kriteria hasil sebagai berikut: a) Klien meningkat dalam aktifitas; b) Mengerti tujuan dan peningkatan mobilitas; c) Mengungkapkan secara verbal perasaan dalam meningkatkan kekuatan dan kemampuan berpindah; d) Memperagakan penggunaan alat; e) Bantu untuk mobilisasi.

Intervensi yang dapat diberikan pada pasien adalah: A) Pemberian posisi independen meliputi 1) Kaji kemampuan fungsi dan luas hambatan pada saat pertama kali dan secara teratur. Klasifikasi sesuai dengan skala 0 sampai; 2) Ubah posisi minimal setiap 2 jam (telentang, miring) dan kemungkinan lebih sering jika klien diposisikan miring ke sisi bagian tubuh yang terganggu; 3) Inspeksi kulit secara teratur terutama di atas benjolan tulang. Secara perlahan masase setiap area kemerahan. Beri bantuan sesuai kebutuhan; B) Terapi latihan kontrol otot meliputi 1) Mulai latihan rentang gerak aktif atau pasif ke semua ekstremitas; 2) Ajarkan latihan seperti latihan kuadriseps atau gluteal, meremas bola karet, dan ekstensi jari tangan dan atau tungkai bawah serta kaki; 3) Bantu klien mengembangkan keseimbangan saat duduk (seperti meninggikan kepala tempat tidur); 4) Tetapkan tujuan dengan klien atau orang dekat untuk meningkatkan partisipasi dalam aktivitas, latihan, dan perubahan posisi, dan melaksanakan aktivitas ADL pasien; 5) Ajarkan klien untuk melakukan peregangan atau aktifitas fisik secara bertahap sesuai toleransi; 6) Ajarkan teknik relaksasi lima jari. Intevensi yang terakhir adalah dengan Kolaborasi: Konsultasikan dengan ahli terapi fisik mengenai 
latihan aktif, resistif, dan ambulasi klien. Setelah dilakukan pengkajian 3x24 jam masalah keperawatan hambatan mobilitas fisik teratasi dengan kriteria hasil kelelahan berkurang, meningkatnya aktifitas fisik.

Masalah keperawatan selanjutnya yang muncul pada pasien kanker payudara post operasi adalah kurang pengetahuan pasien terkait masalah kesehatan yang dialami saat ini. Adapun tujuan dan kriteria evaluasi dari kurang pengetahuan pasien terkait masalah kesehatan yaitu: a) Menjelaskan keadaan penyakit, mengenali kebutuhan akan obat-obatan, dan memahami perawatan; b) Menunjukkan bagaimana cara memasukkan rejimen kesehatan baru ke dalam gaya hidup; c) Menunjukkan kemampuan untuk mengatasi situasi kesehatan dan tetap mengendalikan kehidupan; d) Menunjukkan motivasi untuk belajar; e) Mencantumkan sumber daya yang dapat digunakan untuk informasi lebih lanjut atau dukungan setelah keluar; f) Mengidentifikasi kebutuhan belajar.

Intervensi yang dapat diberikan adalah: 1) Pengetahuan penyakit Aktifitas; a) Kaji pengetahuan klien tentang penyakitnya; b) Jelaskan tentang proses penyakit (tanda dan gejala), identifikasi kemungkinan penyebab. c) Jelaskan tentang program pengobatan dan alternatif pengobantan; d) Diskusikan perubahan gaya hidup yang mungkin digunakan untuk mencegah komplikasi; e) Diskusikan tentang terapi dan pilihannya; f) Eksplorasi kemungkinan sumber yang bisa digunakan/mendukung; g) instruksikan kapan harus ke pelayanan; h) Tanyakan kembali mengenai pengetahuan klien tentang penyakitnya, prosedur perawatan dan pengobatan. Setelah dilakukan intervensi selama 1x24 jam masalah keperawatan kurangnya pengetahuan pasien terkait masalah kesehatan yang dialami saat ini teratasi dengan kriteria hasil klien dapat menjelaskan keadaan penyakitnya, mengenali kebutuhan akan obat-obatan, dan memahami perawatan, dapat menunjukkan bagaimana cara memasukkan rejimen kesehatan baru ke dalam gaya hidup. Dapat menunjukkan kemampuan untuk mengatasi situasi kesehatan dan tetap mengendalikan kehidupan.

Evidence Based Practice yang dapat diberika menjadi intervensi keperawatan maupun kolaborasi dalam penurunan nyeri, kelelahan dan penididikan kesehatan yaitu: 


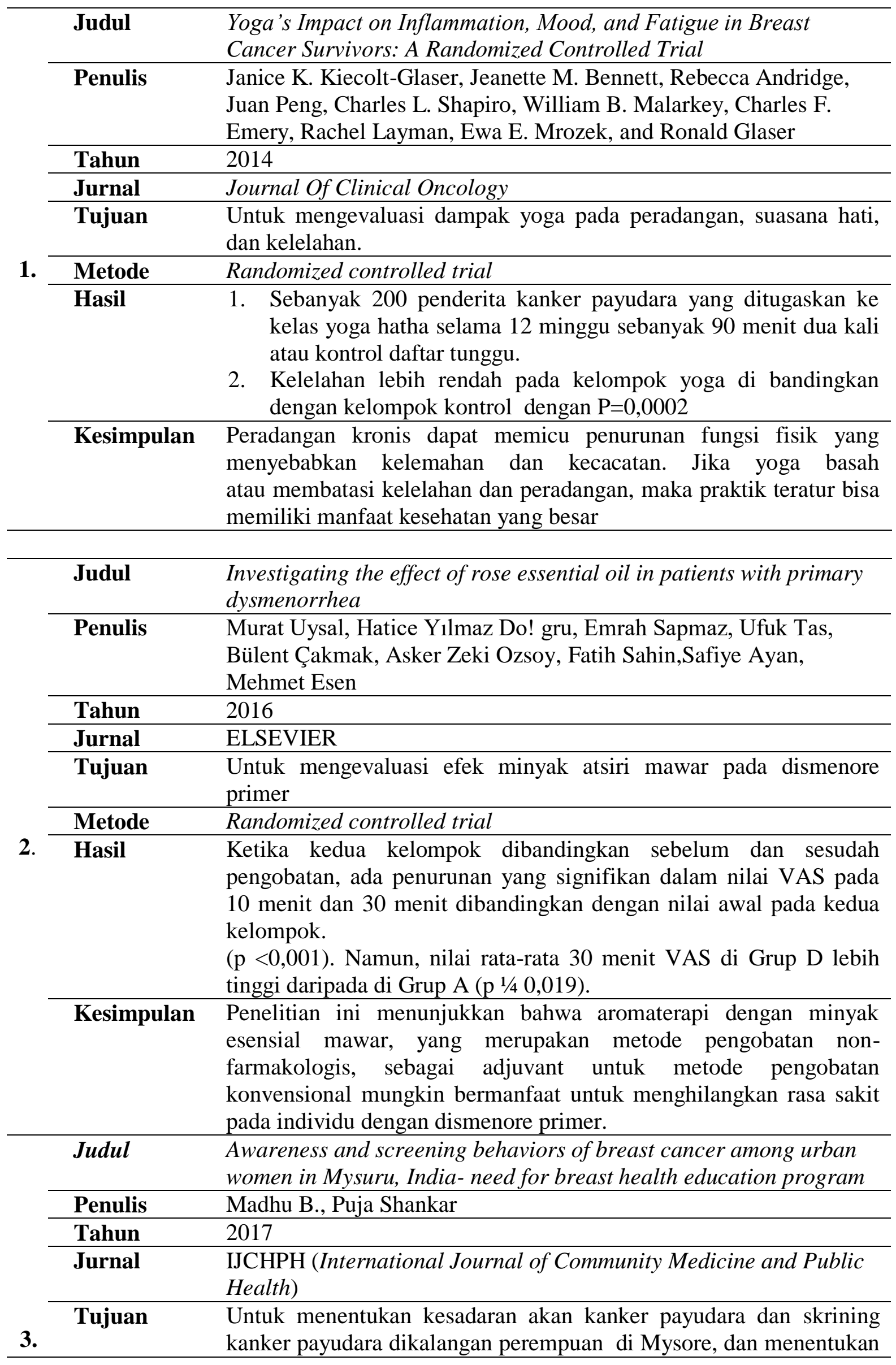




\begin{tabular}{ll}
\hline & $\begin{array}{l}\text { sejauh mana prosedur skrining kanker payudara di praktikkan untuk } \\
\text { mengetahui faktor-faktor yang terkait dengan praktik penyaringan } \\
\text { yang lebih baik }\end{array}$ \\
\hline Metode & Cross Sectional \\
\hline Hasil & $\begin{array}{l}\text { 99\% perempuan sadar akan kanker payudara, 63\% pasien sadar akan } \\
\text { pemeriksaan payudara sendiri, dan 66\% pernah pelatihan BSE satu } \\
\text { kali; hanya 18\% yang mengetahui posisi ideal }\end{array}$ \\
\hline Kesimpulan & $\begin{array}{l}\text { Ditemukan bahwa tingkat praktik yang rendah terkait langung } \\
\text { dengan kurangnya pengetahuan mengenai kanker payudara dan } \\
\text { perlunya pendidikan kesehatan berbasis masyarakat (BHE) untuk } \\
\text { perempuan }\end{array}$ \\
\hline
\end{tabular}

\section{Pembahasan}

Berdasarkan data Riset Kesehatan Dasar tahun 2013, prevalensi kanker payudara di Indonesia mencapai 0,5 per 1000 perempuan. Lebih dari 80\% kasus kanker payudara di Indonesia ditemukan berada pada stadium yang lanjut, dimana upaya pengobatan sulit dilakukan. Sedangkan Jawa Barat merupakan propinsi ketiga terbanyak untuk angka kejadian kanker payudara yaitu 6.701 orang dengan prevalensi 0.3\% (Kemenkes RI, 2015). Seringkali, ketidaktahuan masyarakat terhadap pencegahan sebelum sakit dan perawatan kanker mengakibatkan penurunan kualitas hidup saat sakit (Rahayuwati, Nurhidayah, Ibrahim, Setyorini, 2018)

Lubis \& Hasnida, 2009; Tirgari et.al., 2012 mengatakan Kanker payudara dapat menyebabkan dampak pada beberapa dimensi bagi penderitanya yaitu dimensi fisik seperti nyeri, merasa tak berdaya, lelah, gangguan tidur dan mobilitas yang terganggu. Pada dimensi psikologis penderita mengalami perasaan penuh ketidakpastian, kecemasan dan depresi. Zhou et.al., (2014) pada dimensi sosial, penderita mengalami beban finansial seperti biaya pengobatan yang besar dan merasa terisolir. Pada dimensi spiritual terjadi perasaan bersalah dan konflik batin menerima dan menolak kenyataan. Kumpulan permasalahan tersebut dapat menyebabkan kualitas hidup pasien payudara menjadi rendah.

Kanker payudara perlu dilakukan penatalaksanaan dengan serangkain pengobatan. Pengobatan kanker yang paling sering dilakukan adalah operasi/pembedahan, kemoterapi, terapi radiasi, terapi hormon, terapi kekebalan tubuh, dan/atau kombinasi dari terapi ini. Meski memperbaiki kondisi pasien kanker, terapi tersebut menyebabkan efek samping serta serangkaian gejala fisik dan psikologis (Mustian, 2016). Kwekkeboom et al., (2011) beberapa kondisi yang terjadi pada pasien kanker payudara sampai dapat menghambat kemampuan 
pasien untuk mematuhi protokol pengobatan, melakukan aktivitas hidup sehari-hari dan mempertahankan standar hidup konvensional.

Beberapa gejala yang paling sering dilaporkan akibat dari kanker dan perawatannya adalah gangguan tidur, fatigue, nyeri, hilangnya fungsi fisik, sarcopenia, cachexia, pengeroposan tulang dan gangguan kognitif (Mustian et al., 2016). Klien adalah post operasi kanker payudara hari kedua dengan keluhan nyeri pada daerah operasi payudara kanan, lemas dan lelah. Keluhan ini sesuai dengan gejala yang paling sering dilaporkan diakibatkan dari kanker dan perawatannya diatas.

Menurut Fiorentino et al (2012), nyeri adalah gejala yang umum dan melemahkan pada pasien kanker payudara meliputi nyeri pasca operasi, nyeri payudara dan nyeri yang berhubungan dengan kemoterapi dan radiasi. Nyeri adalah masalah umum pada penderita kanker terutama pada beberapa tahun pertama setelah perawatan. Pada jangka panjang sekitar $5 \%$ sampai $10 \%$ pasien menderita nyeri kronis dan penanganan nyeri ini bisa menjadi masalah klinis yang panjang (Glare et al., 2014). Penderita kanker cenderung lebih menderita nyeri akibat dari pengobatan kanker, seperti radiasi atau nyeri terkait operasi. Nyeri terkait kanker berkontribusi terhadap depresi, insomnia, dan penurunan kualitas hidup bagi banyak pasien kanker (Pachman et al., 2012). Nyeri yang dialami klien adalah nyeri pasca operasi benjolan pada payudara kanan. Klien pada tahun 2015 juga telah menjalani operasi pengangkatan payudara kanan. Operasi pengangkatan benjolan dipayudara kanan tahun 2017 ini adalah ditempat yang sama dengan operasi tahun 2015 .

Selain mengeluhkan nyeri, klien juga mengeluhkan mengalami lemas dan lelah. kelelahan terkait kanker atau Cancer Related Fatigue (CRF) yang dialami klien dapat disebabkan karena adanya gangguan secara psikologis pada penderita kanker payudara. Karakan (2011), menyatakan adanya hubungan antara depresi dengan kejadian fatigue dimana seseorang dengan depresi respon emosionalnya adalah kehilangan energi, sehingga intoleran terhadap aktifitas normal yang dimanifestasikan dengan fatigue. Selain itu, kejadian fatigue pada pasien kanker payudara juga berhubungan dengan gangguan tidur dan nyeri (American Cancer Society, 2014; Stepanski, 2009).

Otto (2007) mengatakan bahwa peran perawat dalam memberikan pelayanan keperawatan dapat dengan memberikan berbagai terapi farmakologis dan non farmakologis. Terapi farmakologis antara lain pemberian obat-obatan antidepresan, analgetik, stimulant yang diberikan sesuai jadwal secara interval selama kemungkinan terjadinya mual dan muntah, dan terapi non farmakologis antara lain latihan psikoedukasi dan terapi perilaku kognitif yang bertujuan untuk memberikan informasi dan konseling tentang fatigue, 
mengurangi dan mengatasi stres, identifikasi sikap adaptif dan maladaptif, kemudian aktifitas dan manajemen energi yang bertujuan untuk mengatur dan merencanakan langkah-langkah dalam mengatur waktu untuk beristirahat dan melakukan kegiatan promosi kesehatan yang progresif, dapat juga melakukan teknik relaksasi yang bertujuan untuk merelaksasikan otototot secara progresif (Mariza dan Kalsum, 2016; Dewi, Rahayuwati, Kurniawan, 2018).

Glaser et al (2014) mengatakan bahwa berdasarkan hasil uji klinis pemberian terapi yoga memiliki manfaat yang besar untuk menurunkan fatigue pada pasien dengan kanker payudara dengan nila $\mathrm{p}=0.002$. lebih lanjut Uysal et al (2016) mengatakan bahwa pemberian aromaterapi mawar juga efektif untuk menurunkan nyeri. Penelitian ini menunjukkan bahwa aromaterapi dengan minyak esensial mawar, yang merupakan metode pengobatan nonfarmakologis, sebagai adjuvant untuk metode pengobatan konvensional mungkin bermanfaat untuk menghilangkan rasa sakit pada individu dengan dismenore primer.

\section{Simpulan}

Setelah dilakukan pemberian asuhan keperawatan berdasarkan evidence based permasalahan pasien teratasi. Dimana pemberian intervensi keperawatan secara holistik pasien merasakan perubahan penurunan pada nyeri, penurunan tingkat kelelahan dan pasien lebih memahami tentang penyakitnya. Hasil telaah dari artikel menunjukkan bahwa efektfitas terapi yoga, serta pemberian aromaterapi mawar dalam intervensi keperwatan untuk nyeri pada kanker juga aman, efektif dan bermanfaat dalam mengurangi intensitas nyeri, kelelahan, berkurang rasa sakitnya, mual dan kecemasan dan melaporkan peningkatan kualitas hidup.

\section{Daftar Pustaka}

American Cancer Association. (2011). Alternative and Complementary Methods for Cancer Management; 2011. Available from: http://www.cancer.org/acs/groups/cid/documents/webcontent/acspc-041660-pdf.pdf.

Dewi, R., Rahayuwati, L., \& Kurniawan, T. (2018). The Effect of Five-Finger Relaxation Technique to The Sleep Quality of Breast Cancer Patients. Jurnal Keperawatan Padjadjaran, $6(2)$.

Glare, P,A., Davies, P,S., Finlay, E., Gulati, A., Lemanne, D., \& Syrjala, K,L. (2014). Pain in Cancer Survivors. Journal of Clinical Oncology. 32 (16), doi: 10.1200/JCO.2013.52.4629.

Huang, S. C., Kuo, S. F., Tsai, P. S., Tsai, C. Y., Chen, S. S., Lin, C. Y., ... \& Hou, W. H. (2019). Effectiveness of Tailored Rehabilitation Education in Improving the Health 
Literacy and Health Status of Postoperative Patients With Breast Cancer: A Randomized Controlled Trial. Cancer Nursing. 10.1097/NCC.0000000000000665.

Karakan S., Sezer S., \& Ozdemir FN. (2011). Factors Related to Fatigue and Subgroups of Fatigue in Patients with End-Stage Renal Disease. National Center for Biotechnology Information, 76(5), 358-64.

Kementrian Kesehatan RI. (2017). Pusat Data \& Informasi. Jakarta Selatan.

Kiecolt-Glaser, J. K., Bennett, J. M., Andridge, R., Peng, J., Shapiro, C. L., Malarkey, W. B., ... \& Glaser, R. (2014). Yoga's impact on inflammation, mood, and fatigue in breast cancer survivors: a randomized controlled trial. Journal of Clinical Oncology, 32(10), 1040.

Lubis, N. L., \& Hasnda. (2009). Dukungan Sosial Pada Pasien Kanker, Pelukah ?: USU Press.

Moorhead, Johnson, Maas \& Swanson. (2013). Nursing Outcome Classification (NOC) Edisi Bahasa Indonesia. Indonesia : Elsevier.

Mustian, K, M., Cole, C, L., Lin, P, J., \& Asare, M. (2016). Exercise Recommendations For The Manajement of Symtoms Clusters Resulting From Cancer and Cancer Treatments. Seminars In Oncology Nurse, 32(4), 383-393.

Nanda. (2015). Diagnosis Keperawatan Definisi \& Klasifikasi 2015-2017 Edisi 10 editor T Heather Herdman, Shigemi Kamitsuru. Jakarta: EGC.

Nugroho, Taufan. (2011). Asuhan Keperawatan Maternitas,Anak, Bedah, dan Penyakit Dalam Yogyakarta : Nuha Medika.

Pachman, D,R., Barton, D.L., Swetz, K,M., \& Loprinzi, C,L. (2012). Troublesome Symptoms in Cancer Survivors: Fatigue, Insomnia, Neuropathy, and Pain. Journal of Clinical Oncology, 30(30), ), doi: 10.1200/JCO.2012.41.7238

Program Studi D-III Keparatan stikes Mercubaktijaya Padang. (2012). Panduan study kasus. Padang.

Rahayu Wahyu. (2011). Menggali, mencegah dan mengobati 35jenis kanker. Jakarta : Victory Inti Cipta.

Rahayuwati, L., Nurhidayah, I., Ibrahim, K., \& Setyorini, D. (2018). Pendidikan dan Promosi Kesehatan tentang Pencegahan Penyakit Kanker melalui Pilihan Jajan pada Siswa-Siswi Sekolah Dasar serta mengenali Potensi Masyarakat dalam Peningkatan Kesehatan. Media Karya Kesehatan, 1(2).

Rasjidi Iman. (2009). Deteksi Dini dan Pencegahan Kanker . Jakarta : CV Sagung Seto.

Sjamsuhidajat R. (1997). Buku Ajar Ilmu Bedah,Edisi Revisi.Jakarta : ECG.

Trigaria, B., Iranmanesh, S., Fazel, A., \& Kalantari, B. (2012). Quality of Life and Mood State Im Iranian Women Post Mastectomy. Clinical Journal of Oncology Nursing, 16(3), E-118-22. 
Uysal, M., Doğru, H. Y., Sapmaz, E., Tas, U., Çakmak, B., Ozsoy, A. Z., ... \& Esen, M. (2016). Investigating the effect of rose essential oil in patients with primary dysmenorrhea. Complementary therapies in clinical practice, 24, 45-49.

Zhou,Z., Hu, Jie., \& McCoy,T,P. (2014). Quality of life among women with breast cancer living in Wuhan, China. International Journal of Nursing Science, 16(3), 118-122. 